\title{
Pemeriksaan Fungsi Hati Terhadap Karyawan Universitas YARSI Menurut Analisa Quantum Magnetik Resonansi
}

\section{Liver Function Examination in YARSI University Employees Using Quantum Magnetic Resonance Analysis}

\author{
Harliansyah ${ }^{1}$, Anna Luthfiana ${ }^{2}$ \\ ${ }^{1}$ Department of Biochemistry, Faculty of Medicine, YARSI University, Jakarta \\ ${ }^{2}$ Department of Neorology, Faculty of Medicine, YARSI University, Jakarta \\ Jalan Letjen. Suprapto, Cempaka Putih, Jakarta 10510 \\ Telephone (021) 4206674, 4206675, 4206676 \\ Email: harliansyah.hanif@yarsi.ac.id
}

\begin{abstract}
Abstrak
Penelitian ini bertujuan untuk memeriksa fungsi hati terhadap karyawan Universitas YARSI yang memenuhi kriteria inklusi dengan menggunakan instrumentasi Analisis Quantum Magnetik Resonansi. Pemeriksaan fungsi hati dapat digunakan untuk skrening efektifitas atau gangguan hati, membantu atas prediksi perkembangan penyakit serta tindak lanjut atas responsi dan evaluasi seperti autoimun. Sinyal-sinyal gelombang elektromagnetik yang dipancarkan oleh tubuh manusia dapat menentukan status kesehatan tubuh. Dari penelitian ini diperoleh hasil sebagai berikut: Indeks massa tubuh $\left(\mathrm{Kg} / \mathrm{m}^{2}\right)$ pada lelaki $(\mathrm{N}=13) \quad 23,39 \pm 3,29$ dan pada perempuan $(\mathrm{N}=12) \quad 25,77 \pm 3,75$; metabolisme protein (lelaki) 145,65 $\pm 28,15$ dan 157,28 $\pm 40,51$ (perempuan); fungsi produksi energi (lelaki) 0,84 $\pm 0,10$ dan 0,84 $\pm 0,08$ (perempuan); fungsi detoksifikasi (lelaki) 0,47 $\pm 0,24$ dan 0,65 \pm 0,22 (perempuan); fungsi sekresi empedu (lelaki) 0,57 $\pm 0,13$ dan 0,59 $\pm 0,15$ (perempuan); level lemak hati (lelaki) 0,46 $\pm 0,16$ dan 0,56 $\pm 0,14$ (perempuan).

Hasil penelitian ini menunjukkan bahwa indeks massa tubuh, metabolisme protein dan Level lemak hati berbeda nyata antara subjek lelaki dan perempuan. Metabolisme protein dapat berbanding langsung terhadap level lemak hati. Ini menunjukkan bahwa degradasi protein yang menghasilkan asam amino bebas dapat digunakan sebagai prekursor pada biosintesa lemak melalui reaksi deaminasi oksidatif. Disini kita membahas bagaimana penggunaan alat Analisis Quantum Magnetik Resonansi.dapat digunakan sebagai metode terbaru dalam prediksi kesehatan manusia.
\end{abstract}

Kata kunci: Metabolisme hati, Quantum Magnetik Resonansi, Test Fungsi Hati

\section{Abstract}

This study aimed to examine liver function in YARSI University employees who met the inclusion criteria using Quantum Magnetic Resonance Analysis instrumentation. Examination of liver function can be used to screen effectiveness or liver disorders, to help predict disease progression and follow up on responses and evaluations such as autoimmune. The electromagnetic wave signals 
emitted by the human body can determine the health status of the body. From this study, the following results were obtained; body mass index $\left(\mathrm{Kg} / \mathrm{m}^{2}\right)$ for male $(N=13) 23.39 \pm 3.29$ and female $(N=12)$ $25.77 \pm 3.75$; protein metabolism (male) $145.65 \pm 28.15$ and 157,28 $\pm 40,51$ (female); energy production function (male) $0.84 \pm 0.10$ and $0.84 \pm 0.08$ (female); detoxification function (male) $0.47 \pm$ 0.24 and $0.65 \pm 0.22$ (female); bile secretion function (male) $0.57 \pm 0.13$ and $0.59 \pm 0.15$ (female); liver fat level (male) $0.46 \pm 0.16$ and $0.56 \pm 0.14$ (female), respectively.

The results of this study indicated that body mass index, protein metabolism and liver fat levels were significantly different between male and female subjects. Protein metabolism can be directly proportional to liver fat levels. This shows that protein degradation that produces free amino acids can be used as a precursor to fat biosynthesis through oxidative deamination reaction. Here we will discuss how the use of the Quantum Magnetic Resonance Analysis instrument can be used as a new tool for human health policy.

Keywords: Liver Metabolism, Quantum Magnetic Resonance, Liver Function Test

\section{Pendahuluan}

Tubuh manusia senantiasa terpapar oleh radiasi gelombang elektromagnetik $(E M R=$ electromagnetic radiation) dalam berbagai intensitas yang tergantung kepada jarak dan lokasi yang mengenai tubuh. Fungsi tubuh manusia yang kompleks sangat dipengaruhi oleh konduktansi listrik, densitas serta permitivitas. Gelombang elektromagnetik memiliki karakteristik terhadap frekwensi, intensitas elektrik dari medan magnet serta polarisasi di daerah area yang terbuka (Sallam and Awad, 2008; Spitz, 2004).

Tanpa disadari penggunaan alat-alat elektronika telah menjadi sumber pembentukan gelombang elektromagnetik yang mempengaruhi kehidupan secara luas. Sumber gelombang elektromagnetik terbagi 2 yaitu, elektromagnetik alami (sinar matahari, bintang, planet) dan elektromagnetik non alami (kabel elektrik TV, komputer, telepon, handphone dan alat elektrik lainnya) (Kumar and Pathak, 2011); Ongel et al., 2009).
Setiap detik terdapat 25 juta sel mengalami pembelahan. Sinyal gelombang elektromagnetik yang terpancar di dalam sistem jaringan tubuh dapat mempengaruhi kondisi dan vitalitas tubuh. Oleh karena itu penentuan sinyal gelombang dapat pula digunakan untuk menentukan status kehidupan dan kesehatan tubuh. Penetrasi gelombang elektromagnetik ke dalam tubuh dan aksi ion pada seluruh organ dapat mempengaruhi potensial membran sel serta distribusi ion dan dipol yang turut mempengaruhi aktivitas enzimatis, sinyal transduksi, sintesis protein bahkan ekspresi gen. Lebih lanjut paparan ini dapat berpengaruh terhadap proses biokimia sel dan dapat mengubah parameter biokimia serta aktivitas enzim dalam serum darah (Sallam and Awad, 2008).

Beberapa jaringan di dalam tubuh dapat berinteraksi dengan EMR untuk menentukan medan magnet. Absorpsi EMR ditentukan oleh temperatur tubuh. Intensitas gelombang elektromagnetik dapat mencapai maksimum jika 
mendekati tower transisi dan sebaliknya dapat melemah jika berada dalam posisi yang jauh (Protheroe, 2013). Hubungan antara nilai medan elektromagnetik $\left(E_{o}\right)$, jarak $(r)$ dan kekuatan transmisi antena vertikal $(P)$ menurut hukum Polk dapat dinyatakan sebagai berikut:

$$
\begin{aligned}
P / 4 \pi r^{2} & =E_{0}^{2} \cdot \varepsilon_{0} \cdot C / 2 \\
& =\left(P / 2 \pi r^{2} E_{0} \cdot C\right)^{1 / 2} \\
& =7,746 \sqrt{ } \mathrm{P} / r
\end{aligned}
$$

Di mana, $E_{0}:$ Medan elektomagnet, $C$ : Kecepatan sinar, $\varepsilon_{0}$ : Permitivitas di daerah bebas, dan $r$ : jarak antara antena transmisi dengan kekuatan radiasi efektif (ERP) dari 50 W, maka,

$$
\mathrm{E}_{\mathrm{o}}=54,76 / \mathrm{r} . \mathrm{V} / \mathrm{m}
$$

Sehingga dapat diketahui bahwa, kekuatan elektromagnetik berbanding terbalik terhadap jarak transmisi (Kumar dan Pathak, 2011; Tavakoli, Farrokh, 2017).

\section{Bahan dan Metoda Penelitian}

1. Jenis Penelitian

Penelitian ini bersifat observasional dengan kaedah deskriptif analitik yang bertujuan untuk mengetahui fungsi hati dari sukarelawan karyawan Universitas YARSI.

\section{Rancangan Penelitian}

Penelitian ini menggunakan rancangan acak sederhana yaitu melakukan observasi atau pengukuran variabel pada satu saat tertentu. Setiap subjek hanya diobservasi satu kali dan pengukuran variabel fungsi hati dilakukan pada saat pemeriksaan tersebut.

Sebanyak 25 orang karyawan Universitas YARSI berusia 25 - 60 tahun digunakan sebagai subjek dalam penelitian ini. Pengujian fungsi hati dari setiap subjek dilakukan dengan mengukur kekuatan medan magnet yang dipancarkan alat kuantum magnetik resonansi. Kelompok I terdiri dari 13 lelaki dewasa diberikan paparan medan magnet dari alat QMRA yang dinyalakan selama 1 menit. Adapun kelompok II terdiri dari 12 perempuan dewasa yang diberikan paparan medan magnet dari alat QMRA yang dinyalakan selama 1 menit.

3. Cara Penetapan dan Besar Sampel

Teknik pengambilan sampling dilakukan secara acak sederhana dengan menggunakan jenis Quota Sampling yaitu sampel yang ditentukan oleh peneliti berdasarkan kriteria inklusi dan eksklusi.

Kriteria Inklusi:

-. Lelaki atau Perempuan dewasa berusia 25- 60 tahun

-. Karyawan Universitas YARSI

-. Bersedia menjadi responden

Kriteria Eksklusi:

-. Tidak bersedia menjadi responden

-. Memiliki gangguan jiwa atau berpenyakit degeneratif (diabetes, TBC, Hipertensi)

4. Jenis Data

Data yang didapat dari penelitian ini berupa data kuantitatif yang diperoleh melalui pemeriksaan analisa kuantum terhadap subjek.

5. Instrumen Pengumpulan Data Instrumentasi utama yang digunakan dalam penelitian ini adalah Quantum Macnetic Resonance Analyzer seri 5BA51A32C409181A. dan Laptop beserta printer.

Cara penggunaan alat Quantum Magnetik Resonansi:

1. Seperangkat alat Quantum resonance yang telah di instal terlebih dahulu selanjutnya dihubungkan kepada komputer 


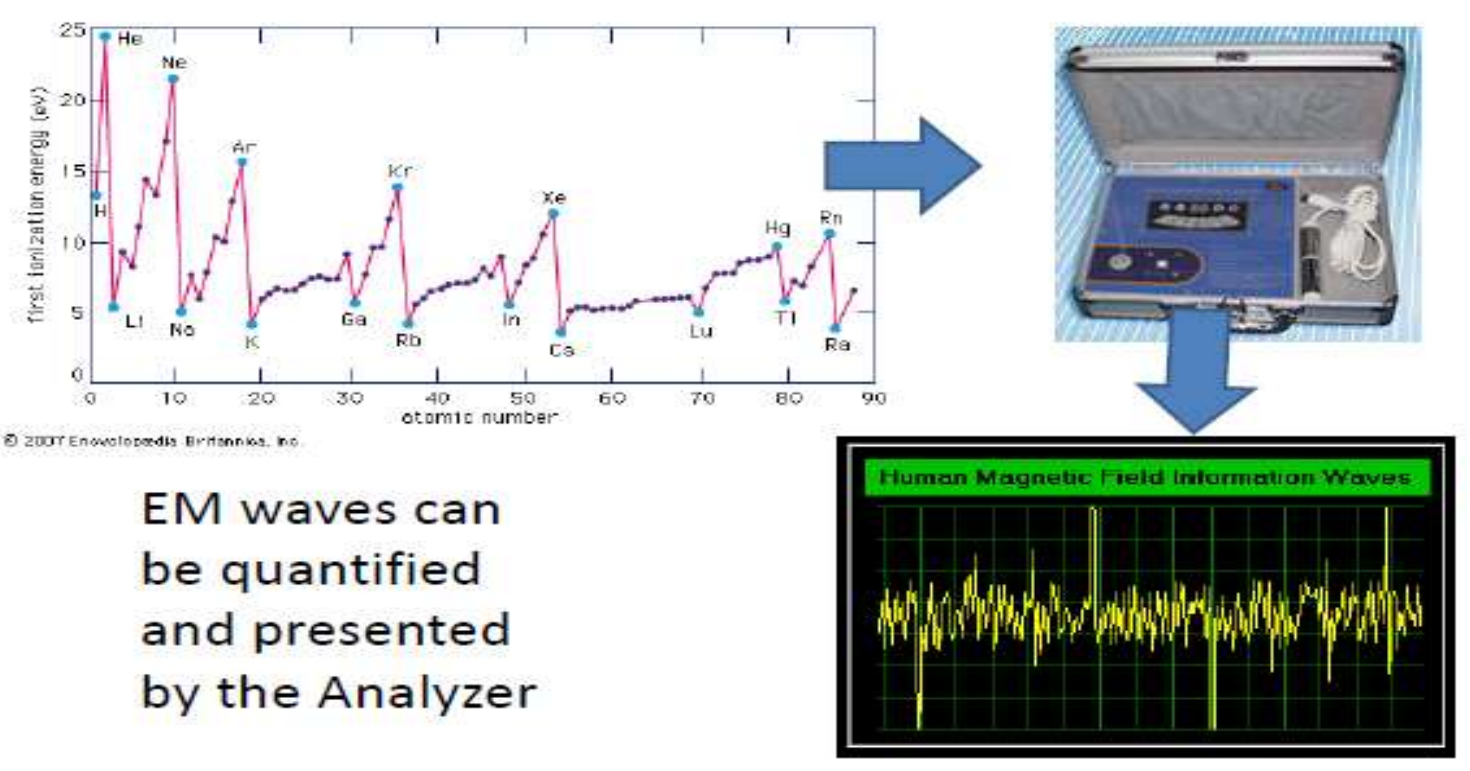

Gambar 1. Alat QMRA seri 5BA51A32C409181A

2. Kemudian USB Drive dihubungkan ke PC dan USB Key (membuka penggunaan perangkat lunak) serta tongkat logam line dihubungkan kepada Mesin.

3. Data-data responden seperti nama, jenis kelamin, tanggal lahir, berat dan tinggi badan diisikan ke dalam sistem, sementara itu tongkat logam berisi sinar infra merah dipegang oleh pasien yang akan diperiksa.

4. Kemudian tunning pada sistem Quantum resonance ditekan dan secara otomatis akan menampilkan hasil tes.

5. Selanjutnya simpanlah setiap data pemeriksaan ini untuk keperluan analisis berikutnya.

\section{Analisis Data}

Seluruh data yang diperoleh dalam penelitian ini selanjutnya diolah secara statistik menggunakan program SPSS for Window.

\section{Hasil Penelitian}

Dari 25 orang sukarelawan yang mengikuti pemeriksaan fungsi hati secara QMRA dan lolos dalam kriteria inklusi terdapat
13 orang lelaki (52\%) dan 12 orang perempuan $(48 \%)$ dengan rentang usia 25 - 60 tahun. Distribusi subjek berdasarkan usia, Indeks Massa Tubuh (IMT), Metabolisme Protein, Fungsi Produksi Energi, Fungsi Detoksifikasi, Fungsi Sekresi Empedu dan Level Lemak Hati disajikan pada tabel 1.

Metabolisme protein berawal dari pencernaan protein makanan dan diserap oleh usus untuk dikirim ke hati serta dikonversi atau direorganisasi. Asam amino hasil konversi ini kemudian dimetabolisme untuk memproduksi berbagai protein yang berguna dan memenuhi kebutuhan sel tubuh. Hati juga akan mengurai protein yang tidak berguna secara proteolitik menjadi asam amino, kemudian asam amino diubah menjadi urea lalu dibuang oleh ginjal atau usus. Gangguan metabolisme protein pada pasien dengan penyakit hati dapat berupa penurunan produksi protein hati, penurunan pembentukan urea dan penurunan metabolisme asam amino aromatik. Penurunan protein plasma menyebabkan hipoalbuminemia serta asites (pada pasien dengan hipertensi portal). 
Tabel.1. Hasil Periksaan Fungsi Hati Menurut Cara QMRA

\begin{tabular}{lcc}
\hline \multicolumn{1}{c}{ Parameter } & Lelaki $(\mathrm{N}=13)$ & Perempuan $(\mathrm{N}=12)$ \\
\hline Indeks Massa Tubuh $\left(\mathrm{Kg} / \mathrm{m}^{2}\right)$ & $23.39 \pm 3.29$ & $25.77 \pm 3.75$ \\
Metabolisme Protein & $145.65 \pm 28.15$ & $157.28 \pm 40.51$ \\
Fungsi Produksi Energi & $0.84 \pm 0.10$ & $0.84 \pm 0.08$ \\
Fungsi Detoksifikasi & $0.47 \pm 0.24$ & $0.65 \pm 0.22$ \\
Fungsi Sekresi Empedu & $0.57 \pm 0.13$ & $0.59 \pm 0.15$ \\
Level Lemak Hati & $0.46 \pm 0.16$ & $0.56 \pm 0.14$ \\
\hline
\end{tabular}

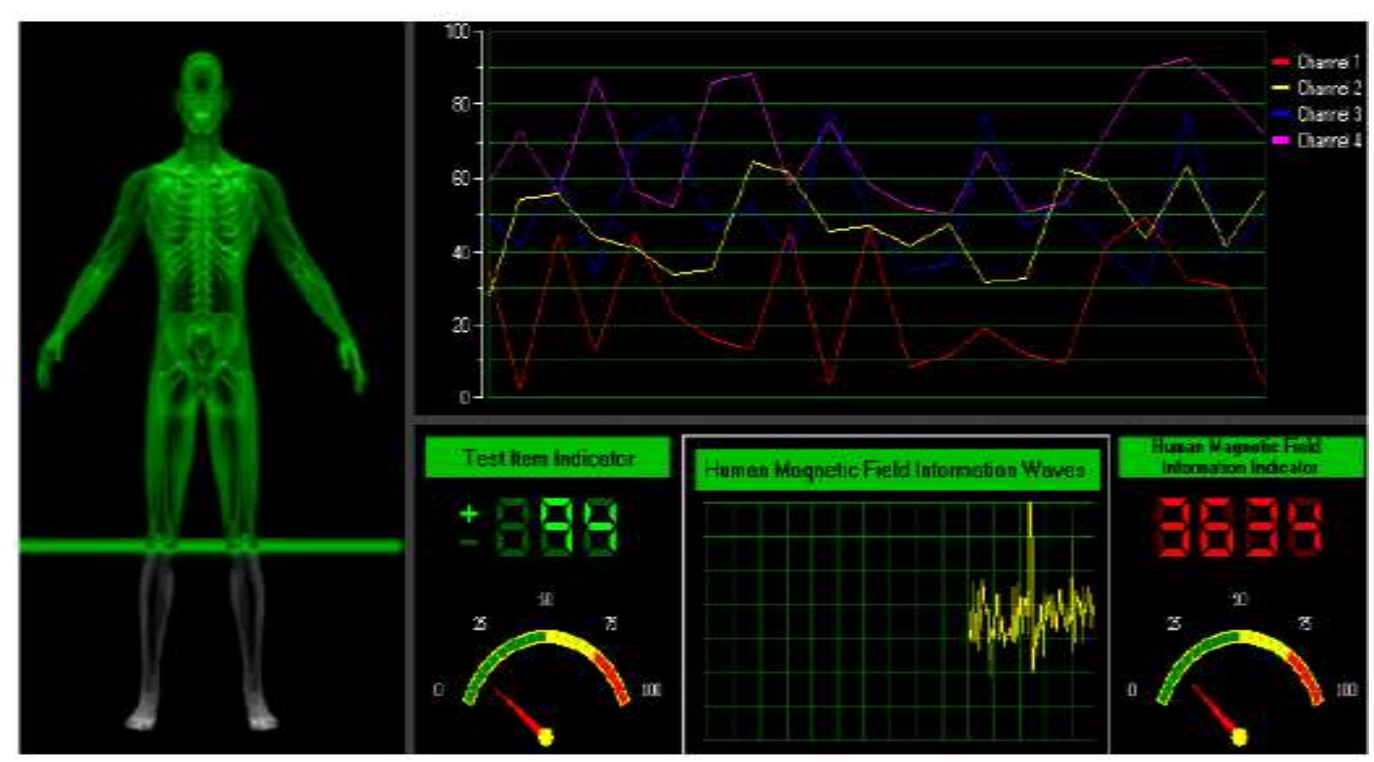

Gambar 2. Model Analisa Fungsi Hati Menggunakan Alat QMRA

Seperti halnya protein, senyawa (pembersihan) untuk menguraikan zat karbohidrat berupa polisakarida akan dicerna dan selanjutnya monomer-monomer sakarida seperti glukosa, fruktosa akan dibawa ke hati untuk kebutuhan sel dan kemudian kelebihan gula akan diubah menjadi glikogen lalu disimpan. Setelah makanan berlemak dicerna, hati selanjutnya akan mengkonversi lemak menjadi energi. Selain menghasilkan energi, makanan juga akan menghasilkan beberapa racun dalam proses pencernaan dan proses metabolisme. Hati bersama beberapa enzim di dalamnya melaksanakan proses detoksifikasi berbahaya (alkohol dan amonia) menjadi zat tidak berbahaya (seperti karbon urea, air dan CO2) untuk dibuang keluar dari tubuh.Fungsi sekresi empedu akan menghasilkan empedu yang merupakan produk akhir dari metabolisme di hati, serta memiliki peran dalam pencernaan lemak dan menyerap vitamin larut lemak $A, D, E$ dan K. Garam empedu ini berperan juga sebagai emulgator alami.

Dari tabel 1 terlihat bahwa kelompok lelaki maupun perempuan memiliki level metabolisme protein, fungsi produksi energi, 
fungsi detoksifikasi dan fungsi sekresi empedu yang normal. Hanya kandungan lemak hati untuk kedua kelompok secara rata-rata adalah berubah, di mana kelompok lelaki mengalami abnormal ringan $(+)$ dengan indeks rata-rata $0,46 \pm 0,16$ sedangkan perempuan mengalami abnormal sedang $(++)$ dengan indeks $0,56 \pm$ 0,14 .

Perbedaan kandungan lemak hati dari batas normal menunjukkan pola kehidupan yang cenderung mengkonsumsi makanan berkalori tinggi serta kurangnya aktivitas fisik sehingga mengalami kegemukan. Metabolisme Protein dapat berbanding langsung terhadap Level Lemak Hati. Hal ini menunjukkan bahwa degradasi protein bebas dapat sebagai prekursor pada biosintesa lemak melalui reaksi deaminasi oksidatif.

\section{Diskusi}

Secara umum sel hati normal mengandung lemak. Namun akumulasi lemak hati melebihi $10 \%$ dari berat hati dikenal sebagai kandungan lemak hati. Dari data-data di atas lemak hati dianggap belum berbahaya, karena fungsi hati tidak terganggu. Walau demikian untuk jangka panjang, lemak hati berpotensi menjadi penyebab kerusakan hati dan sirosis. Perlemakan hati terjadi akibat akumulasi lemak di dalam sel hati. Jika ruangan pada hati dan sel-sel terpenuhi oleh lemak maka, proses filtrasi aliran darah dan detoksifikasi hasil metabolisme terganggu di dalam hati, akibatnya aliran darah akan penuh dengan racun dan lemak. Beberapa penyakit hati seperti Steatosis (perlemakan hati) dan Stealohepatitis (perlemakan hati disertai peradangan) dapat terjadi yang diawali seperti perut terasa penuh, pusing, mual dan letih. Dalam kondisi seperti ini tentu saja pasien akan mengalami gangguan dalam bekerja sehingga produktivitas lambat laun akan menurun (Csomos and Feher, 1992).

\section{Simpulan}

Pemakaian alat Quantum Magnetik Resonansi (QMRA) dapat digunakan untuk mengukur tingkat dan jenis respon soal yang diuji, dan dibandingkan dengan materi referensi yang ada. Secara umum alat ini dapat memprediksi tanpa gejala serta menangkap perubahan-perubahan patologis sel dan prekursor penyakit. Dengan mengambil tindakan prediksi kesehatan saat ini, maka secara efektif gangguan penyakit dapat dipelajari serta mengetahui tindakan apa yang diperlukan agar perkembangan penyakit dapat diatasi.

\section{Saran}

Disarankan kiranya beberapa faktor yang menjadi parameter kesehatan lainnya perlu diperiksa terhadap karyawan Universitas YARSI guna meningkatkan prestasi kerja.

\section{Ucapan Terima Kasih}

Terima kasih disampaikan kepada Prof. Dr. Jurnalis Uddin, PAK selaku Ketua BPH Yayasan YARSI yang telah membiayai penelitian ini lewat dana Hibah Internal Universitas YARSI tahun anggaran 2016-2017.

\section{Daftar Pustaka}

Consales, C., Merla, C., Marino, C., Benassi, B. 2012. Electromagnetic Fields, Oxidative Stress and Neurodegeneration. Int. J. of Cell Biology.ID. 683897.1-16.

Csomos, G., Feher, J. 1992. Free Radicals and Liver. Springer - Verlag. 
Kumar, S., Pathak, P.P. 2011. Effect of electromagnetic radiation from mobile phones tower on human body. Indian. J. Radio \& Space Physics. 40: 340-342.

Li, Y., Lu, G. 2009. The Research on the Harm of Biological Effect of Mobile Phone Radiation to Human Body. Progress in Electromagnetics Research Symposium, Beijing, China, March 23-27.

Ongel, K., Gumral, N., Ozguner, F.2009. The Potential Effects of Electromagnetic Field: A Review. Cell Membranes and Free Radical Research. 1(3-1): 85-89.

Ozdemir, F., Kargi, A. 2011. Electromagnetic waves and human health, In. Electromagnetic Waves. Zhurbenko, V (Ed). ISBN. 978-953-307-304-0. InTech.473-492.

Protheroe, R.J. 2013. Essential Electromagnetism. ISBN. 978-87-4030404-6. Ventus Publ.
Sallam, S.M., Awad, A.M. 2008. Effect of static magnetic field on the electrical properties and enzymes function of Rat liver. Romanian J. Biophys. 18 (4): 337-347.

Serra, R.M; Olivera, L.S. 2012. Nuclear magnetic resonance quantum information processing. Phil. Trans. R.Soc. A. 370: 4615-4619.

Spitz, D.R., Azzam, E.I., Li, J.J., Gius, D. 2004. Metabolic oxidation/reduction reactions and cellular responses to ionizing radiation: A unifying concept in stress response biology. Cancer and Metastasis Revies 23: 311-322.

Tavakoli, M., Farrokh, D. 2017. Magnetic resonance spectroscopy for quantitative analysis of fatty liver disease: a systematic review. Rev. Clin. Med. Vol. 4 (2): 45- 49 . 